\title{
第65回 日本循環器学会学術集会
}

\section{循環器教育セッション I～心不全の治療}

\section{慢性心不全の治療法の現況 \\ 一EBMに基づいてー}

山口大学医学部器官制御医科学講座 循環病態内科 松 嵭 益德

\section{病態理解の変遷}

近年，慢性心不全に対する病態の理解は大きく変 化してきた．従来より心不全は“心筋収縮機能の障 害により身体の必要する血液量（酸素）を十分に供 給できなくなり，運動能力の低下や肺うっ血，およ び末梢臓器に浮腫を生じた病態”であるとされ，そ の治療法も心収縮機能を改善し，心拍出量を増加さ せ心不全の主要症状である臟器浮腫をとることが主 目的であった。この治療概念は，急性心不全患者の 生命保持の為には重要で, 現在でも最も有効な治療 法として用いられている．1980年代にはいり，末梢 循環と心臓との相互関係から心不全を考え治療しょ うとする概念が生まれ，急性，慢性心不全の治療に 種々な血管拡張薬が用いられるようになってきた。 特に経口動静脈拡張薬は短期的にも長期的にも血行 動態の著明な改善と症状の軽減をもたらした。以前 より，心筋障害により心拍出量が低下すると循環系 のホメオスターシスを維持するため神経体液系因子 の活性，その中でも交感神経系が充進することが知 られていたが，近年，レニン・アンギオテンシン・ アルドステロン（RAA），アルギニン・バゾプレッ シン，エンドセリン，ニューロペプチドYなどの血 管収縮因子の他に心房性ナトリウム利尿ペプチド (ANP) やその関連物質，内皮因子（EDRF，NO）, アドレノメデュリンなどの血管拡張因子の活性も立 進し，心不全はそれらが複雑に関連した一つの症候 群であるとする考え方が生まれてきた。

\section{EBMに基づく治療法}

治療法も大きく変化し，過剩に艺進した血管収縮 因子の是正, 中でもレニン・アンギオテンシン・ア ルドステロン系の抑制は，血行動態の改善だけでな く, 心肥大・拡大の是正を生じ，その生命予後を改 善することが多くの臨床試験で証明された。また， 従来の考え方では使用禁忌であった $\beta$ 受容体遮断薬 の有効性も広く認められるようになってきた。現在， 慢性心不全治療の大きな目標は 1 ) 神経体液因子の 是正，2）心肥大 - 拡大の抑制，3）致死的不整脈 の治療であると言っても過言ではない。

\section{1、ジギタリス剤}

ジギタリス剤は200年以上前から心不全治療薬と して用いられてきたが, 最近までその薬効を大規模 臨床試験で検討した報告はなかった１997年，6800 例の正常洞調律の慢性心不全患者を対象に行われた 大規模試験（Digitalis Investigation Group：DIG, 図 1$)^{\prime \prime}$ では利尿薬, ACE阻害薬との併用で, 総死 亡率にはプラセボ群との差はみられなかったが，入 院率および心不全悪化による死亡・大院率の有意な 低下が認められた。心房細動例では無論, 洞調律患 者でもその有效性が確立されたと言える。

\section{RAA系抑制作用薬}

RAA系の抑制作用薬であるACE阻害薬は当初, 動 静脈拡張作用による血行動態の改善が慢性心不全治 療における主作用と考えられていたが，多くの大規 模臨床試験の結果，それに加え増殖因子としての RAA系の抑制作用が慢性心不全患者の病態の改善 


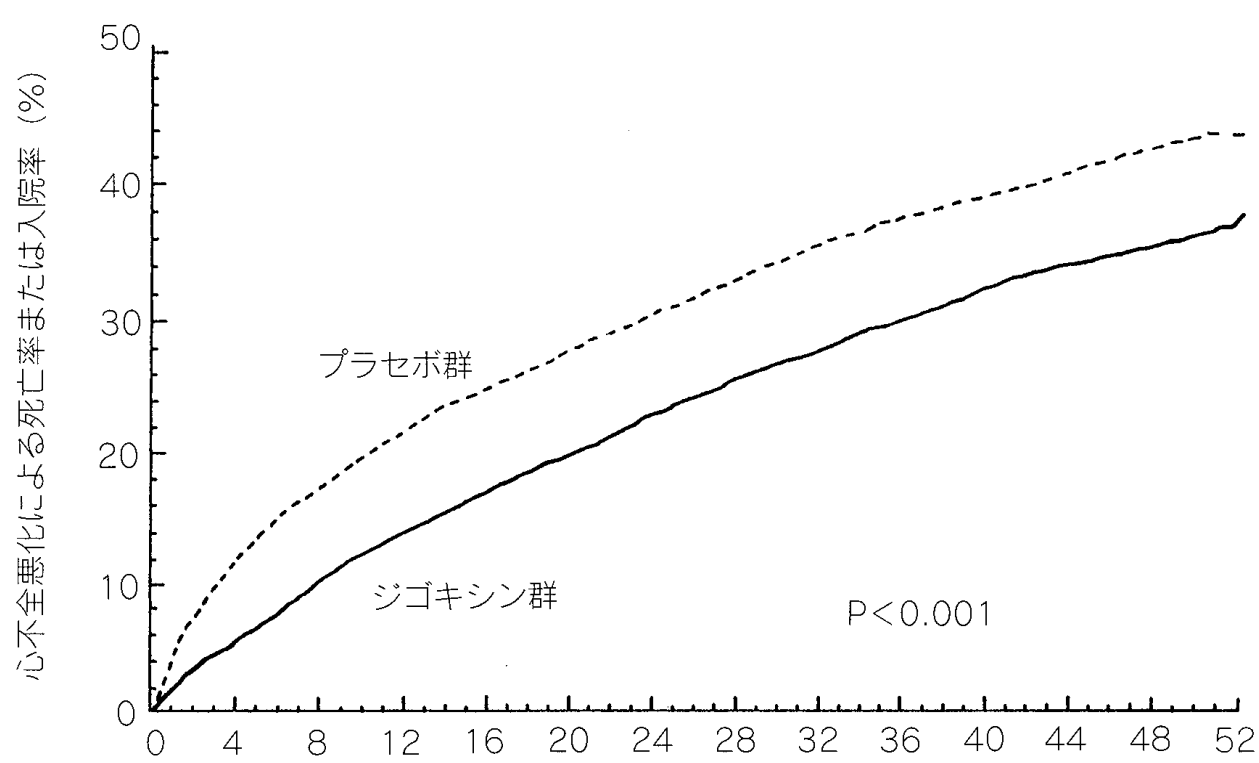

症例数

追跡期間（月）

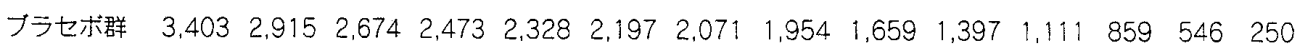

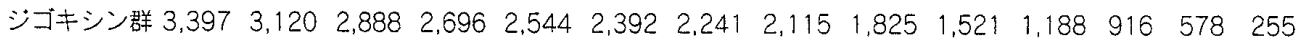

図 1 ジゴキシン群およびプラセボ群における心不全悪化による死亡率または入院率. ジゴキシン群で死亡率または入院率の有 意な低下がみられる.（参考論文 1 ) より引用.)

図 2 エナラプリル群およびヒドララジン +ISDN併用群の累積死亡率. 2年後 の死亡率を比較すると, エナラプリ ル群 $(18 \%)$ は併用群 $(25 \%)$ より も有意に低く（Risk Reduction 28\%, $\mathrm{P}=0.016)$ ，その傾向はその後も続い たが，全試験期間では有意な差はみ られなかった $(P=0.08)$.（参考文献 4)上り引用.)



に大きく貢献していることが実証された。 その抑制 薬であるACE阻害薬の長期投与により慢性心不全 患者の生命予後が有意に改善できることが多くの臨 床試験で証明された (SAVE ${ }^{2)}, \mathrm{SOLVD}^{3)}, \mathrm{V}-\mathrm{HeFT}$ II ${ }^{11}$, 図 2, CONSENSUS ")など)。また, 最近, 抗 アルドステロン薬の長期使用により, 重症心不全患
者の生命予後が改善されることが報告 (Randomized Aldactone Evaluation Study: RALES $^{(5)}$ ，図 3) され，慢性心不全治療における RAA系抑制の重要性がさらに増してきた。最近，本 邦でも使用されはじめたアンギオテンシン受容体拮 抗薬の慢性心不全治療の効果についても大変期待さ 
図 3 スピロノラクトン群とプ ラセボ群の生存曲線. 3 年間の試験期間でスピロ ノラクトン群で死亡リス クが30\%低下した。（参考 文献 6 )上り引用.

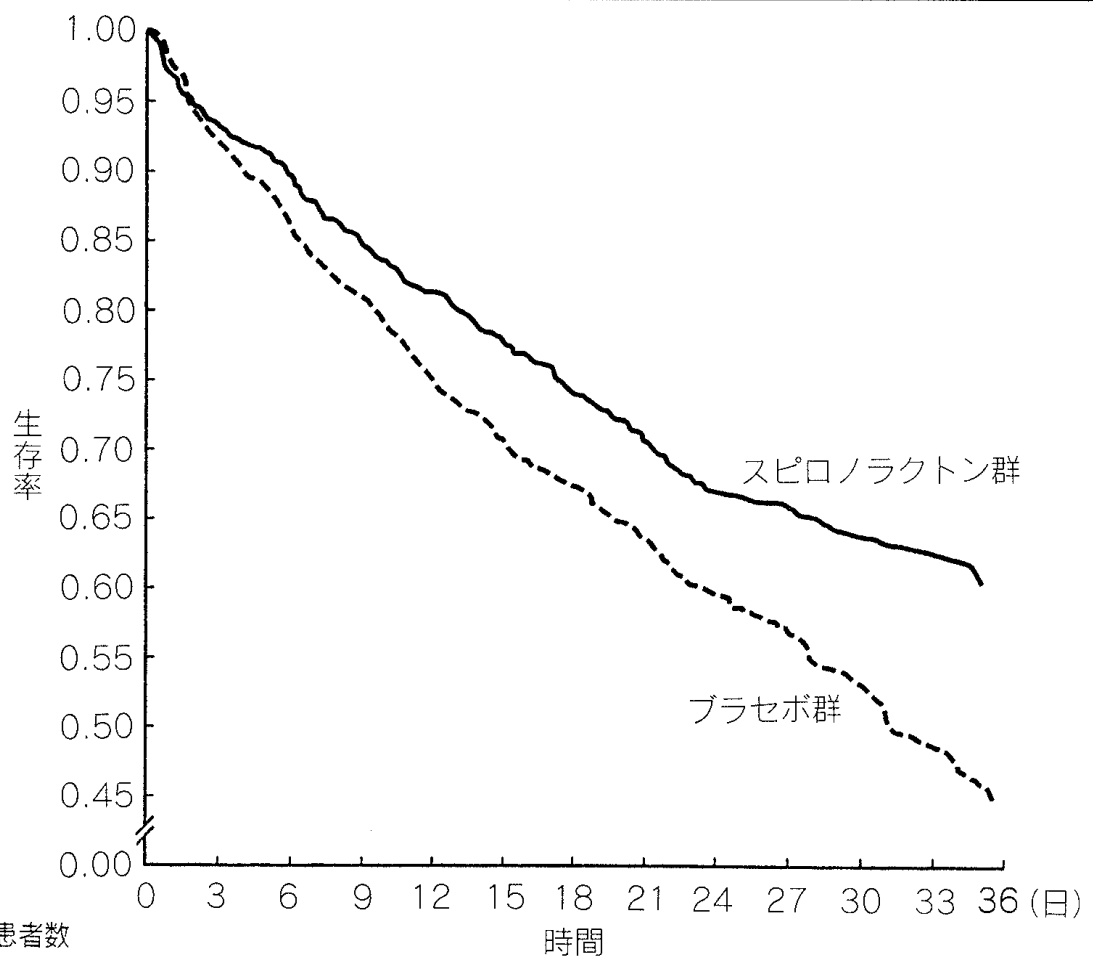

リスクした患者数 ブラセボ群 $\begin{array}{lllllllllllll}841 & 775 & 723 & 678 & 628 & 592 & 565 & 483 & 379 & 280 & 179 & 92 & 36\end{array}$ スピロノラクトン群 $822766739698669639608 \quad 526 \quad 419 \quad 316 \quad 193 \quad 12243$
れているが, 現在のところACE阻害薬に勝る効果が あるかどうかの確立した評価は得られていない (ELITE II ). しかし，昨年11月，アンギオテンシン 受容体拮抗薬とACE阻害薬の併用がACE阻害薬単 独投与より，心不全悪化イベントの発現を有意に抑 制したとの報告（Val-HeFT）があり，今後さらなる 臨床試験の結果が期待されている。

\section{3. $\beta$ 受容体遮断薬}

1975年, Waagstein 7)らにより初めて慢性心不全患 者治療における $\beta$ 受容体遮断薬の有効性が報告され た。この時期，慢性心不全はまだ血行動態的な観点 から治療されて抢り，多くの治療法はいかに心拍量 を増すか，またうっ血を軽減させるかに向けられて いた， $\beta$ 受容体遮断薬の使用は，これらの概念とは 全く逆説的な治療法であり，この論文に対する反響 は大きかったものの，それをすぐに臨床の場に応用 する考え方には至らなかった。その後も同じグルー プの研究者らにより， $\beta$ 受容体遮断薬を用いた大規 模な臨床試験が行われた。当初, 多施設から無効と する結果もいくつか報告されたが，その多くは観察 期間の短い臨床試験が多く，現在ではその有効性は 確立されたと言える。一般に内因性交感神経刺激作



図 4 メトプロロール群とプラセボ群の累積死亡率曲線. メ トプロロール群で有意な死亡率の低下がみられ，死亡 リスクは34\%減少した。また，突然死のリスクも $41 \%$ 低下した。(参考文献 8)より引用.)

用（ISA）を持たない $\beta$ 受容体遮断薬が有効である とされているが，以前より言われていた $\beta$ ，選択性 (metoprolol ${ }^{8)}$ ，図 4, bisoprolol ${ }^{9)}$ ，図 5 ) の重要性 は明らかでなく，最近では血管搪張作用を併せ持っ た $\beta$ 受容体非選択性（laberolol， carvedilol ${ }^{(0)}$ ，図 6, 


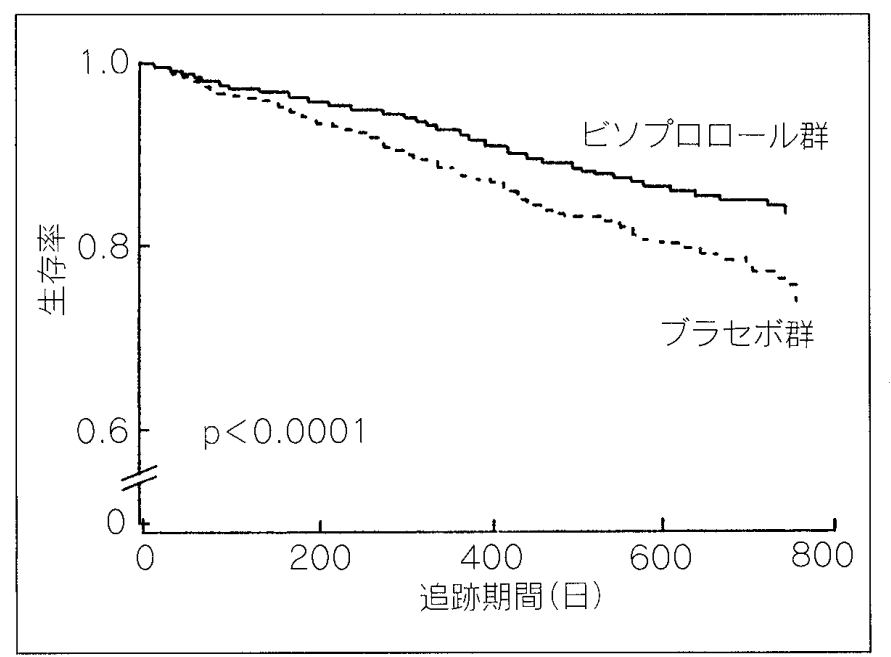

図 5 ビソプロロール群とプラセボ群における生存率曲線. 全死亡はビソプロロール群 $(11.8 \%)$ で，プラセボ群 （17.3\%）に比し有意に低下した（死亡率リスクは34\% 減少, $P<0.0001)$. 突然死もビソプロロール群で有意 に減少した $(P<0.0011)$. (参考文献 9$)$ より引用. $)$

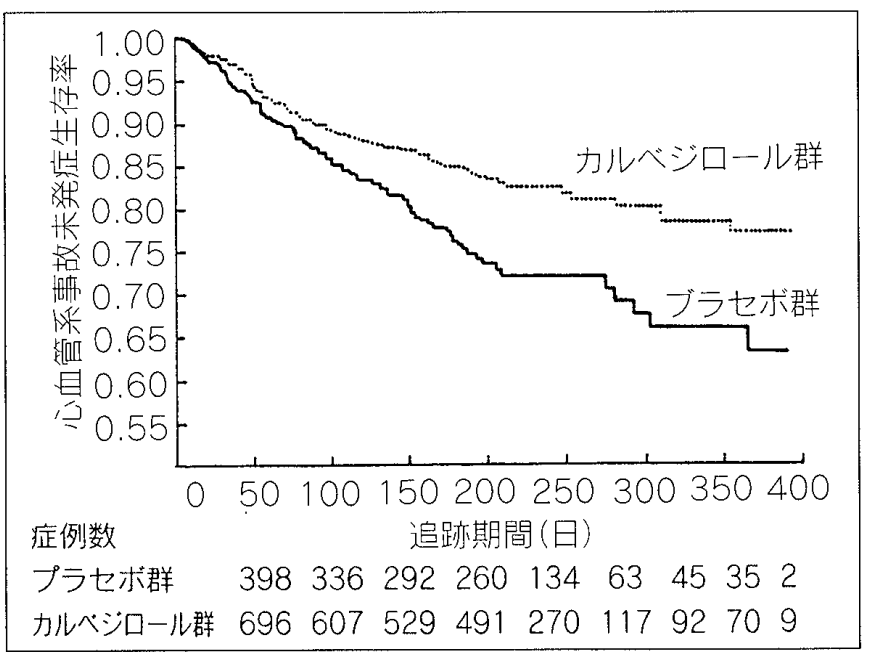

図 6 カルベジロール群およびプラセボ群における生存率曲 線. カルベジロール群では，プラセボ群に比し心血管 系疾患による死亡・入院リスクが38\%低下した（P< 0.001）（参考文献10）より引用.)

buchindololなど）によっても良好な効果がみられて いる。また，当初は $\beta$ 受容体遮断薬投与により，心 筋細胞の $\beta$ 受容体のup-regulationがその有効性の機 序であると報告されたが，up-regulationを伴わない 状態でも有効性は実証されており，未だ明らかな機 序は解明されていない。一般には心拍数低下による 心筋酸素需要と供給関係の改善, RAA系の抑制効果, 拡張期特性の改善, 細胞内Ca過負荷の是正などが考 えられている。最近, 日本で初めて, 中等度 (NYHA II m- III）の慢性心不全患者193名を対象にして， 受容体遮断薬 (carvedilol) の有効性をみる本格的な
多施設，長期投与の臨床試験が施行された ${ }^{12}$ 。 その 結果，欧米で報告されている有效投与量の半分以下 の投与量で, プラセボ投与量に比し心不全の悪化お よび悪化による入院の頻度（危険率）の約 $90 \% の$ 減 少が報告された。 $\beta$ 受容体遮断薬の有効性を日本人 を対象とした実証した初めての臨床試験であり，注 目されている.しかし, 現在, 本邦で心不全治療で 保険適用されている $\beta$ 受容体遮断薬はまだなく，ま た，使用する場合にはごく少量から始め，注意深い 観察のもとで増量しなければならない。

\section{Ca拮抗薬}

多くのCa拮抗薬の心不全に対する臨床試験では, 好ましい結果は得られていないが, amlodipineでは 非虚血性心不全患者でのみその総死亡率，心事故発 症率の有意な低下が認められた（PRAISE I ）。しか し，対象者を増し非虚血性心不全患者だけを対象と したPRAISE II ではプラセボとの間に総死亡率，心 事故発症率に差異がないことが報告された。 diltiazemでは比較的軽症心不全例では心事故発症 率の低下をみたが，肺うっ血のある重症例では心事 故は増加した（MDPIT)。いずれにしてもCa拮抗薬 だけでは慢性心不全患者を治療することは困難であ り他剂との併用，または心不全患者で血圧のコント ロールを必要とする例に前記薬荗を使用する。

\section{5. 経口強心薬}

PDE阻害薬をはじめ, 多くの経口強心薬が開発さ れその臨床試験が行われたが，慢性心不全患者を対 象とした大規模試験で明らかな生命予後改善効果が 認められた薬剤はない。しかし, 慢性心不全患者の もう一つの治療目的であるQOLの改善には経口強 心薬が有効であったという報告もみられる，最近， 日本で279名の中等度の慢性心不全患者を対象とし たpimobendanの長期投与試験が行われ ${ }^{(3)} ， 1$ 年間の 実薬投与群（1.25mgまたは $2.5 \mathrm{mg}$ を 1 日 2 回投与) ではプラセボ群に比し，死亡率，心不全の悪化によ る入院，生活活動能力を合わせた評価で有意な改善 が認められた。また，二重盲検試験終了後，約 1 年 間のfollow-up期間においても，pimobendan 投与群 では非投与群に比し，死亡率，心不全悪化による入 院の有意な減少が認められた。しかし，経口強心薬 


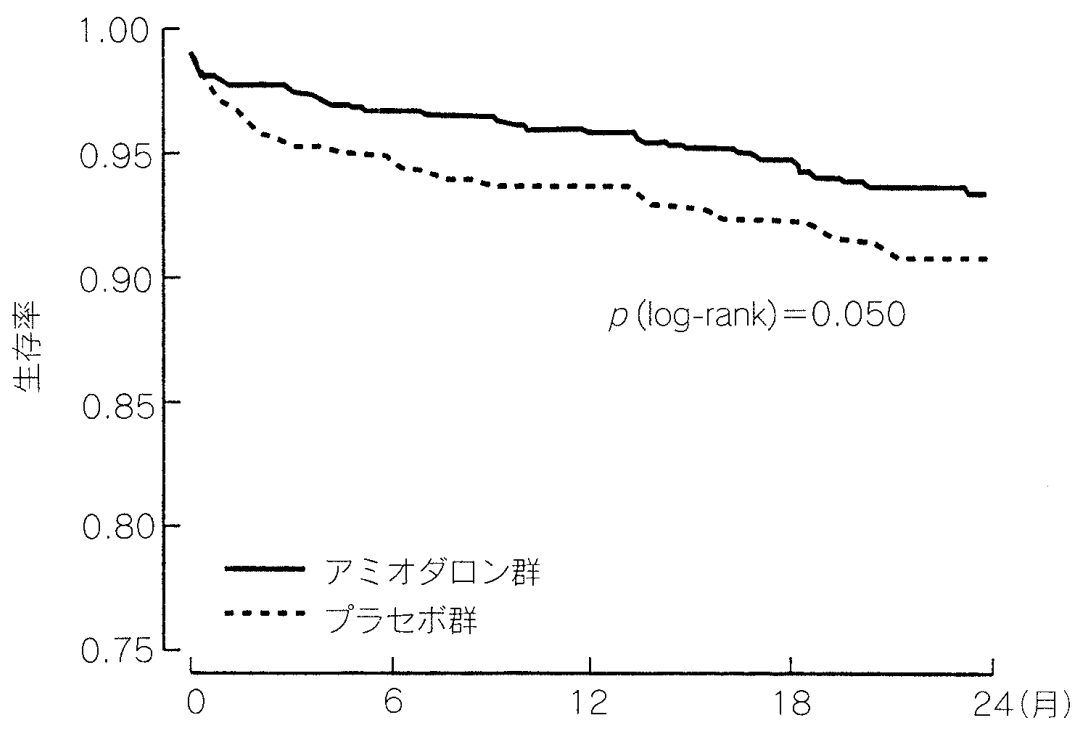

患者数 無作為割り付けからの期間

$\begin{array}{llllll}\text { プラセボ群 } & 743 & 687 & 651 & 543 & 464 \\ \text { アミオダロン群 } & 743 & 696 & 659 & 543 & 472\end{array}$

図 7 アミオダロン群とプラセボ群における生存率曲線（不整脈死・心停止からの蘇生を回避した患者の割合)。(参考文献14) より引用.）

の投与は催不整脈効果もあり，その投与には常に細 心の注意をはらい，少量投与から行うことが望まれ る.

\section{6. 難治性不整脈の治療}

頻発する心室性期外収縮や非持続性心室頻拍も心 臓突然死の危険因子となるが，この様な非致死性不 整脈の抗不整脈薬による治療は，生命予後を悪化さ せることが知られている. 現在， $\beta$ 遮断薬とアミオ ダロンで生命予後改善効果が報告されているが', 図 7, その使用には注意を要する。持続性心室頻拍 や心室細動の致死性不整脈にも $\beta$ 遮断薬, アミオダ ロンの有効性が報告されているが予後改善効果は未 だ証明されていない，現在，抗不整脈薬の選択には Sicilian Grambitに基づく治療ガイドラインが推奨 されている.

非薬物治療としては, カテーテルアブレーション による不整脈発生部位やリエントリー回路の除去も 試みられるが，虚血性心疾患や特発性心筋症例での 有効性は低い. 心室細動や, 重篤な血行動態の悪化 を呈す持続性心室性頻拍の既往例では植え达み型除 細動器の適応となる ${ }^{15 !}$.

\section{0- 献}

1) The Digitalis Investigation Group. The effect of Digoxim on Mortality and Morbidity in Patients with Heart Failure. N Engl J Med 1997 ; 336 : 525-533

2) Pfeffer MA, Braunwald E, MoyeLA, et al. Effect of Captopril on Mortality and Morbidity in Patients with Left Ventricular Dysfunction After Myocardial Infarction : Results of the Survival and Ventricular Enlargement Trial. N Engl J Med 1992 ; 327 : 669-677

3) The SOLVD Investigators. Effect of Enalapril on Survival in Patients with Reduced Left Ventricular Ejection Fraction and Congestive Heart Failure. N Engl J Med 1991 ; 325 : 293-302

4) Cohn JN, Johnson G, Ziesche S, et al. A Comparison of Enalapril with Hydralazine / Isosorbide Dinitrate in the Treatment of Chronic Congestive Heart Failure. N Engl J Med $1991 ; 325: 303-310$

5) The CONSENSUS Trial Study Group. Effects of Enalopril on Mortality in Severe Congestive Heart Failure : Results of Cooperative North Scandinavian Enalopril Survival Study (CONSENSUS). N Engl J Med 1987 ; $316: 1429-1435$

6) Pitt B, Zannad F, Remme WJ, et al. The Effect of Spironolactone on Morbidity and Mortality in Patients with Severe Heart Failure. N Engl J Med 1999 ; 341 : 709717

7) Waagstein F, Bristow MR, Swedberg K, et al. Beneficial 
Effect of Metoprolol in Idiopathic Dilated Cardiomyopathy. Lancet $1993 ; \mathbf{3 4 2}: 1441-1446$

8) MERIT-HF Study Group. Effect of Metoprolol CR/XL in Chronic Heart Failure : Metoprolol CR/XL Randomized Intervention Trial in Congestive Heart Failure (MERIT -HF). Lancet 1999 ; 353 : 2001-2007

9) CIBIS- - Investigators and Committees. The Cardiac Insufficiency Bisoprolol Study • (CIBIS- • ): A Randomized Trial. Lancet $1999 ; 353: 9-13$

10) Packer M, Bristow MR, Cohn JN, et al for the US Carvedilol Heart Failure Study Group. The Effect of Carvedilol on Morbidity and Mortality in Patients with Chronic Heart Failure. N Engl J Med 1996 ; 334 : 13491355

11) Packer M, O'Connor CM, Ghali JK, et al. Effect of Amlodipine on Morbidity and Mortality in Severe Heart Failure. N Engl J Med 1996 ; 335 : 1107-1114
12) Hand $S$, et al. Multicenter Carvedilol Heart Failure Assessment Trial (MUCHA). J Cardiac Failure $2000 ; 6$ : 31 (Supplement)

13) Pimobendan Heart Failure Investigation Group. The Effects of Pimobendon on Mortality and Morbidity in Patients with Mied to Moderate Chronic Heart Failure A Placebo-Controlled, Randomized, Double-Blind Long Term Study. J Cardiac Failure 2000; 6 : 88 (Supplement)

14) Julian DG, Gamm AJ, Frangin G, et al. Randomized Trial of Effect of Amiodarone on Mortality in Patients with Left-Ventricular Dysfunction after Recent Myocardial Infarction : EMIAT. Lancet 1997 ; 349 : 667-674

15) Antiarrhythmics versus Inplantable Defibrillators (AVID) Investigators. A Comparison of Antiarrhythmic Drug Therapy with Implantable Defibrillator in Patients Resuscitated from Near-fatal Ventricular Arrythmia. N Engl J Med 1997 ; 337 : 1576-1583 